\title{
Staging the Male earch for Identity
}

Submitted by

Magda Ibrahim Taher Abd El Hamid

\author{
Assistant lecturer \\ Faculty of Education
}



This study aims at analyzing how the theme of male identity is staged/dramatized in Sam Shepard's Curse of the Starving Class(1977) focusing on the different kinds of human relationships; male/female and male/male relationships. However, as its title suggests, this study will mainly focus on how the male characters in Curse are staged as they are in a continuous search for their male identity. The deep analysis of the play demonstrates that studying Shepard's plays gives a clear image of the American masculinity inside home. The play is clearly concerned with the issues of masculinity and the continuous struggle of its male characters for defining their manhood in a world that is not of their own making.

Sam Shepard is one of the main figures of the postmodern American playwrights. In most of his plays, Shepard focuses on depicting the character of the American man and the struggles he faces in order to identify his masculine identity. His male protagonists struggle to prove themselves to be men, but are limited, even entrapped, by the images of masculine identity imposed upon them by their exclusively materialistic culture.

Shepard's men are hardly positive images of completed and individualized masculinity or identity, however much Shepard himself may or may not have intended them to be so. Their actions usually do not lead them into a secure masculinity. Further, they are usually unable to cope with the worlds which they have helped to create, although they desire to blame the failings of their own creations on women or on 
systems of culture. This desire to escape or to deny their own entrapments often leads to violent, abusive behavior. When Shepard's men fail in achieving the impossible unity of their identity, they seek an avoidance or escape that nevertheless fails to free them from their problems. They flee to the desert, to alcohol, to the past or to their fantasies of the past, but their problems of identity do not go away. They participate in self-defeating and often self-destructive escapist behavior because they are unable to reconcile their perception of their male identity.

Shepard started writing his "family" plays in the late seventies; Curse of the Starving Class (1977) was the first of his family plays which also included Buried Child (1978) and True West (1980). According to Shepard, the family is the base of everything: "What doesn't have to do with family? There isn't anything...Even a love story has to do with family...everyone is born out of a mother and a father, and you go on to be a father. It's an endless cycle" (Adler, 111). He chose to focus on the family because it resembles the whole society. Shepard wanted to criticize his community through presenting the deteriorating American family. In Curse of the Starving Class, the pivotal theme is the festering decay of this family, and its characters suffer from identity crisis. This all-inclusive male identity crisis appears to be the result of the destruction of the American family.

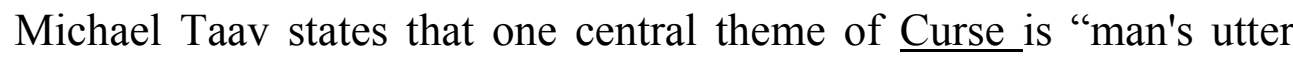
powerlessness" in the face of this crisis (44). For McDonough, Shepard's focus on male crises of identity has tended to relegate his female characters and their concerns to the sidelines of his 
plays....His male character's explorations of subjectivity are always given center stage. (65)

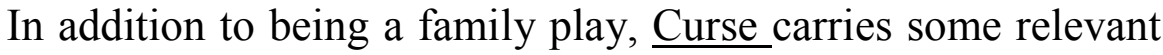
motifs: one of them is the shaping effect of 'heredity' on the characters of the play. Heredity plays an essential role in forming one's identity. The curse that Shepard refers to in the play's title is a socio-economic and cultural curse that has a great power to the extent that Benedict Nightingale accurately describes it as the "inexorable handing over of loss from one generation to the next" (Taav 39), and which Ella, the wife, laments as being:

Always there. It comes onto us like a nighttime. Every day I can feel it. Every day I can see it coming. And it always comes. Repeats itself. It comes even when you do everything to stop it from coming. Even when you try to change it. And it goes back. Deep. It goes back and back to tiny little cells and genes. To atoms. To tiny little swimming things making up their minds without us. (41)

So, heredity in Curse is a great inexorable force which the protagonist cannot fully acknowledge until it has destroyed him. This is clear in the characters' names. According to Martin Tucher, the mother and daughter (Ella and Emma), and the father and son (Weston and Wesley) are given echoing names, a device that suggests a "tradition is being carried on". Here Shepard is suggesting that "father and son, mother and daughter, are carrying on the tradition on which they are subject both as adherents and as victims" (127). The new 
generation is compelled to play the same stereotypical roles assigned to them by the previous generations. The end-result of this everoccurring process is loss/crisis of identities.

Doris Auerbach also asserts that the "curse" of the title refers to the "inevitability of generation after generation repeating the same meaningless act. The curse of the father is passed on to the son" (qtd King 55). As Weston, the father says: "I never saw my old man's poison until I was much older than you. Much older. And then you know I recognized it? Because I saw myself infected with it."(35). Thus, the "curse" of the play's title is both biological and familial and social and economic. The titular starvation is multilayered, not only physical, emotional, and spiritual but socio-cultural as well.

From the first moment of the play, the staging of male identity crisis is very clear. The play starts with the son Wesley carting off the wood from a broken-down door; the home as a place of shelter and security has been violated. The kitchen's door is broken, and Wesley is trying to fix it. Wesley is a young cowboy wearing a "sweatshirt, jeans, and cowboy boots" (5).Wesley's act of fixing the door shows his connection with this house. He wants to protect the house and the family, so Wesley appears to be a caring and a helpful son at the beginning of the play. Ella, the mother, and Wesley are speaking together in the kitchen. Ella asks her son to stop fixing the door. Despite his mother's objections, the young man attempts to impose a sense of order on the chaos of his surroundings.

Ella: (after while) You shouldn't be doing that. 
Wesley: I'm doing it.

Ella: Yes, but you shouldn't be. He should be doing it. He's the one who broke it down.

Wesley: He's not here.( 5 )

The staging of the character of Wesley also helps in representing how men are searching for their true male identities. Wesley is trying to fill in the space where the father is missing. The father is usually a model for his son to follow. The absent father, Weston, is not a good model for his son. Due to the weakness and the failure of the father, the son is trying to step in and play the role of the patriarch. Wesley here seems to be suffering; he is in pain, and a feeling of loneliness dominates over him: "Makes me feel lonely". This loneliness is a common characteristic of all Shepard's characters who face masculinity crisis. Wesley is attached to his roots because he thinks his roots can help him in defining his male identity. He is connected with the land of the west: "I could smell the avocado blossoms...I could feel this country close like it was part of my bones." (7). He has nothing to support him so he clings to the house as something to be possessed or the place where he has grown up, so it may help him to realize his identity.

Wesley here may represent every son who is lost and cannot find a good father to imitate. Shepard shows the American man as he fails to prove his masculine identity because of the struggles he faces inside his family. For Wesley, his identity crisis begins when 
he starts mixing those beautiful feelings with the terrible state and the quarrels that happen between his parents: "Feet coming. Feet walking toward the door. Feet stopping...Foot kicking the door. Man's voice. Dad's voice. Dad calling Mom. No answer...Wood splitting...Glass breaking...Man cursing. Man going insane. Man yelling. Shoulder smashing. Whole body crashing. Woman screaming. Mom screaming"(8).

Notably, from the first moment of the play, the absence of Weston, as the head of the family, and the broken door of the family house are very significant elements of staging the male identity crisis. The father fails to fulfill any conditions of American identity, a failure that begins within the family, the basic social unit of the American society. His dissatisfaction with his family life is evident from the start. After an all-night drinking wine, Weston returns early in the morning to discover he has been locked out, and promptly destroys the front door in a rage before getting back into the car and tearing off into the darkness ("a very big man, middle aged, wearing a dark overcoat which looks like it's been slept in, a blue baseball cap, baggy pants, and tennis shoes. He's unshaven and slightly drunk") (25). So before he even appears on stage, Weston's violent temper and inability to play the role of protector to his family are revealed. According to David DeRose, Weston's violent attack symbolizes the destruction of the "protective circle of the family" (92). He threatens the safety of his family, and leaves them defenseless. For Madachy, "both literally and symbolically, Weston's destruction of the door represents the lack of protection that he provides for his family" (82). 
And the son suffers from his father's behavior and from the terrible relationship between his parents.

Although Shepard claims that he is not in favour of violence or masculine macho attitude, consciously or unconsciously he has always been fascinated by violence and its traces more or less appear in almost all of hisplays. In an interview with Michiko Kakutani of $\underline{\mathrm{New}}$ York Times in 1984, he makes his own comment and description about it:

I think there is something about American violence that to me is very touching...In full force it's very ugly, but there is also something very moving about it, because it has to do with humiliation. There is some hidden, deeply rooted thing in the Anglo-male American that has to do with inferiority that has to do with not being a man, and always, continually having to act out some idea of manhood that is invariably violent. This sense of failure runs very deep. (qtd in Hart 72)

Weston's inability to perform his required masculine role makes him feel inferior and humiliated. So he acts violently. When Shepard's men fail in achieving the impossible unity of their identity, they seek an avoidance or escape that nevertheless fails to free them from their problems. They flee to the desert, to alcohol, to the past or to their fantasies of the past, but their problems of identity do not go away. This desire to escape or to deny their own entrapments often leads to violent, abusive behavior. For Shepard, this violence is caused by the male himself, and there is nobody else to blame (Hall 95). 
However, some of his male characters accuse their counterparts of being the source of male aggression. Shepard suggests that the source of violence is not woman as the males claim, but instead, it is the man himself. According to Ann C. Hall, Shepard thinks that the violence in male characters derives from a "lack", a problem inherited in them. Man uses violence in order to make the female obey, and to prove his power in front of the other males. In other words, they try to suppress this lack using violence.

Thus, Shepard uses violence in the opening scene as a tool that helps in staging the father's male identity crisis. Although the father does not appear yet, his actions reveal his violence and bad state. He broke the door when he was drunk. The father, here, is an addict to alcohol. Shepard presents the father as corrupt because of his addiction. Instead of being the one who protects his family, Weston brings fear to his family members, especially the mother: "I was scared" (6). Mokbel states: "patriarchal authority which is the base of the traditional family fails here because the father's role is opposite to that of the traditional 'breadwinner' father." (20)

As the play continues, Weston articulates his failure at fulfilling the function of a patriarch by offering threats instead of security. When he finds out that his wife Ella is not home, he demands to know where she is, screaming "Don't try protecting her! There's no protection! Understand! None!'(165). Instead of providing the protection that the family is supposed to offer its members, Weston terrorizes his family, becoming more of a threat than a guardian. His threatening attitude forces his family to seek protection 
outside home, as Ella turns to a sordid real estate developer for security: "[Weston] can't hurt me now! I've got protection! If he lays a hand on me, I'll have him cut to ribbons!" (173). And, at times, his children feel the same fear of their father, as both Emma and Wesley reflexively react to Weston's presence by wanting to flee the stage.

Beyond his inability to provide the physical comfort and protection of a family unit, Weston also fails to supply sustenance for his family or to play the role of the breadwinner. The refrigerator, a focal point of the play due to the characters' constant inspection of its contents, remains mostly empty throughout the play. Roudané states that "a prominent part of the stage set is a refrigerator into which one or other of the characters is often found staring, and the defeated observation of Nothing"(110). Weston's identity crisis is very obvious when he continues speaking to himself, while opening the refrigerator to find it empty: "I don't know why we keep a refrigerator in this house." He becomes angry, so hunger pushes him to be upset and hopeless: "What's everybody waiting for, a miracle! THERE'S NO MORE MIRACLES! ...IT'S ONLY ME! MR. SLAVE LABORS HIMSELF COME HOME TO REPLENISH THE EMPTY LARDER!” (26). Weston represents every father who lost hope in his ability of being a real father. His violence is a symptom of his failure disease.

For Mokbel, "poverty is one of the reasons of man's crisis" (21). When a man feels that he is unable to provide food and security for his family, he will become upset and hopeless. Upon one of Weston's random returns to the house, he stocks the fridge full with 
artichokes, which Ella promptly throws out, astutely pointing out, "It's a joke bringing artichokes back here when we're out of food" (171). For Tucher "the central metaphor of the play is food, and its lack of it. The food that feeds the sexual, romantic, sentimental, and ideal appetites as well as the stomach.”(124)

One of the main problems that lead to poverty is unemployment. Weston is jobless: "I thought Dad got fired" (13) says Wesley. Weston's family is poor because he is unable to work and to support them; a matter that not only affects Weston himself but also his son. Wesley's male identity crisis, then, can be related to the poor and unsatisfactory condition of the family. Wesley, as all members of the family, keeps opening the refrigerator. Wesley is upset, and he believes his family is from the starving class.

Wesley: I'm hungry.

Ella: How can you be hungry all the time. We're not poor. We're not rich but we're not poor.

Wesley: What are we then? (12)

In $\underline{\text { Curse }}$, the family has nothing to eat, and this is one of the important reasons for their problems. Shepard wants to show that the poor condition of the postmodern family leads also to man's crisis.

And even when Weston experiences his fake rebirth and attempts to create a better family atmosphere, significantly by making a ham-and-eggs breakfast for his son, Weston ends up eating all the 
food he prepares. Weston, then, becomes more "parasite than patriarch" (Madachy 79), and when the family needs him the most, he abandons them, presumably to "start a whole new life" down in Mexico (60). Peterson explains this point saying that:

The possibility of change, of breaking out of the cycle, suggested by Weston's conversion in the beginning of Act III is dispelled by Wesley's entrance. His transformation into and ultimate displacement of Weston is confirmation that the cyclical pattern has only been temporarily disrupted and not broken. (56)

Weston searches for his male identity by escaping the current situation of loss. In fact, he is entrapped in certain stereotypical images for the masculine identity that he cannot realize. These are all illusions. He has no prospects in escaping.

The staging of male identity crisis is also very clear in the setting of the play which is realistic and very significant. The play is set at a kitchen in a farm house that is located in an avocado farm in the West, away from the city and its modern life. All the incidents of the play take place inside the kitchen that includes a table, four metal chairs, a refrigerator and a small stove. This signifies the entrapment of the family members and the emptiness of the refrigerator of food conveys an almost metaphysical feeling of suffering and desperation. The frustration and spiritual "hunger" shared by the characters is objectified by the physical hunger. 
Economic privation compels certain behaviors. According to Peterson, "economic hardship reduces one's ability to function in a rational manner. In terms of the socio-anagogic hierarchy, one regresses from the socio-political hierarchy into the natural hierarchy dominated by biological and/or animalistic motivation" (68).

Behavioral regression is dramatically represented in Wesley's brief monologue to the lamb in Act I.

Wesley: (staring at lamb) "Eat American Lamb. Twenty million coyotes can't be wrong."

He crosses to refrigerator and opens it. He stares into it.

Wesley: You're out of luck. Santa Claus hasn't come yet.

He slams refrigerator door and turns to lamb. He stares at lamb.

Wesley: (to lamb) you're lucky I'm not really starving. You're lucky this is a civilized household. You're lucky it's not Korea and the rains are pouring through the cardboard walls and you're tied to a $\log$ in the mud and you're drenched to the bone and you're skinny and starving, but it makes no difference because someone's starving more than you. Someone's hungry. And his hunger takes him out- side with a knife and slits your throat and eats you raw. His hunger eats you, and you're starving.( 25) 
The "curse" of economic deprivation compels the members of "the starving class" into modes of behavior more animalistic than human.

Wesley places the lamb inside the kitchen. The lamb is affected by 'maggots'. Placing a lamb inside a kitchen is not a usual thing; it delineates the domestic being supplanted by the wild. Shepard used this image to illustrate the male identity crisis. Here, the lamb "represents Wesley himself, for both are infected and need treatment. Wesley is suffering from identity crisis" (Mokbel 21). Unless his family helps him, he will be destroyed. According to Tucher, "the images of food, of a constantly empty refrigerator, and of a chicken and a lamb....are peppered throughout the play. Shepard's inventiveness in the use of these images proves hilarious and poignant in turns."(129)

When Weston appears for the first time in the play by the end of the first act, he enters the house to find the lamb inside the kitchen. $\mathrm{He}$ is astonished, so he speaks with himself: "Is this inside or outside?" According to Greg Barnhisel, one of the main themes in the play is the struggle between the inside and the outside (15). The family is destroyed because the outside is attacking the inside. The lamb is supposed to be outside the house, so it represents the lack of security and privacy; everything can penetrate into the house.

Weston's house, then, is not safe. It lacks family coziness and unity, and this is one of the reasons behind his weakness. By confining his setting to a single location, Shepard limits the movement of his characters. His male characters cannot escape their destiny of loss. 
They are entrapped within certain masculine roles that they cannot play. In terms of Burke's spatial movement or progression, the basic dialectic is between "in" and "out"--one either remains entrapped within the house (the traditional/stereotyped roles) or escapes out of the house (untraditional roles).(97)

Weston's physical safety depends on relocation. But Weston's escapist impulse has ideological underpinnings as well. He has failed to achieve any semblance of his male identity; through the course of Curse, Weston systematically breaks down at every facet of his character: he fails as a landowner, a businessman, and a family man. And all of Weston's failures stem from his inability to profit from the land he owns.

Before the family plays that begin with Curse, women were largely absent from Shepard's plays and often tended to be "caricatures" when present, but in dealing with the family, Shepard cannot avoid presenting women's roles even if he might prefer not to do so. According to McDonough, in the family plays, we begin to see more clearly in Shepard's presentation of male/female relationships, how the "men struggle to control their women as a way to maintain an image of themselves as powerful men, and how the women suffer from this treatment by their men, but also ultimately elude their control."'(67)

Staging the relationship between Ella and her husband reveals the wife-husband relationship of the postmodern era which significantly concretizes the male identity crisis. Mokbel says: 
"according to patriarchal authority the wife depends on her husband for living and protection. In the postmodern period, the roles of men and women changed leading to a change in their relationship and in the patriarchal authority as well" (21). In Curse, Ella is free to act the way she likes neglecting her husband and his role as a man, for she has very little affection or even respect for her husband.

Ella rejects the fact that they are poor because she has a dream of going to Europe after selling the house: "They have everything in Europe. High art. Paintings. Castles. Buildings. Fancy food." Ella rejects the life of poverty: "I'm selling the house, the land ...Everything" (14). On the other hand, Wesley, who is connected with his house and land, rejects her idea: "This is where I live" (15). He prefers being poor to leaving his house. He is connected with their roots at the beginning, and both of them turn to be like their fathers at the end. For Mokbel, Shepard always demonstrates that there is no hope for heroes to survive in the postmodern period. They will be haunted by the terrible image of their fathers (21). In Curse, Wesley needs to see his father strong despite his weakness. The postmodern man, represented by Wesley, does not have a hero to imitate. Wesley, then, will lose his male identity like his father.

Ella decides to sell the house and to start a new life without even telling him: "He's not going to kill me. I have every right to sell. He doesn't have a leg to stand on" (16) Weston lost one of his legs, so physically he lacks power. Weston's weakness and failure to perform his masculine role give Ella a reason to neglect him. Ella not only scorns her husband, but she betrays him as well. She makes a sexual 
relationship with Taylor, the man who buys the house from her. She goes outside the house with him without telling her husband. The relationship between Ella and Weston reveals that man is no more superior in his relation with his wife. He is weak physically and spiritually, so this new role makes him face male identity crisis.

Ella, the mother figure, does not engage in looking after her family on a full time basis and can be seen to behave in a manner which does not embrace the stereotypically feminine roles of helpmate and homemaker. However, these qualities in Ella allow her to appear as a negative representation of women, as she prefers to cater to her own selfish needs and to ignore the needs of her family in the process. Ella is represented as being an ineffective mother figure. She appears to be periodically concerned about her children, but her actions continually contradict that concern. This results in her giving the impression of being a strangely ambivalent character. According to David Savran:

Sometimes she is the concerned mother looking out for her children; other times she is the selfish woman embittered by all she has missed in life. At one moment she is concerned about the danger to Emma in taking a wild horse, and the next she is complacent about it since she does not want to bother herself to go look. (72)

Ella reveals herself to be an incapable nurturer when she takes her daughter Emma's chicken to feed herself. She appears to be the concerned mother when she tells her daughter about menstruation, but demonstrates that she is an inadequate nurturer since she lies about it. 
Ella: But I want you to know the truth. I want you to know all the facts before you go off and pick up a lot of lies. Now, the first thing is that you should never go swimming when that happens. It can cause you to bleed to death. The water draws it out of you. (8)

Shepard implies that women's ability to produce offspring and their inability to nurture their children allow for a "curse" to continue to plague the starving class.. The character of Ella proves Yolks' words that "Shepard's female characters are ultimately reminiscent of traditional representations of women since their behaviour reinforces patriarchal attitudes" (50) and those women who do not look after their children are not performing their jobs or the stereotypical roles correctly. According to Doris Auerbach:

Sam Shepard has created a series of mother figures who are too weak to counteract the violence of the fathers. They lack the will and the power to restore order in their world, to bring about a family in balance, one that can nurture its children.... Shepard portrays an eternal battle between the women gatherers who settle down, grow food and create civilization, and men, the nomadic hunters, who survive by violence and flee the ties of family and commitment.(King 53,54)

Here, the character of Ella is untraditional female figure, as she is powerful and has the will to act and to sell the house without even telling her husband. Although Ella is more powerful than her husband, 
the image that Shepard wants her to represent is a negative one. Shepard actually reinforces the patriarchal nature; he affirms the patriarchal myth which privileges male subjectivity at the expense of the female by objectifying and abusing her. Rather than subverting or deconstructing the masculinist bias-male violence and an emphasis on male subjectivity at the expense of female subjectivity-Shepard's plays often reinforce this bias as a given and present it dramatically as particularly American. Shepard creates female characters who attempt to disrupt stereotypically feminine behavior, but he suppresses their ability to authentically accomplish this, or to benefit from behaving in ways which are not stereotypically feminine.

As for Emma, Ella's daughter, she appears as a rebellious young lady. She resembles the postmodern woman who wants to free herself from man's authority. Emma has been touted as one of the strongest female characters that Shepard has ever created (Marranca, 31; Whiting 497). She is vibrant and vociferous, determined to get away from the family and to create her own life. Yolks says: "Shepard's desire to dismantle tradition is apparent in his attempt to create female characters who do not behave in ways which include stereotypical feminine behaviour" (50). Her exploration of possible lifestyles and her seeming ability to choose her path stand in contrast to Wesley, whose sole thoughts and allegiances are to maintaining the family farm. The "curse" here occurs when Emma attempts to accord her life some degree of normalcy and order. She appears onstage dressed in her 4-H Club uniform and carrying her 4-H Club charts. Immediately, she meets with resistance. First her mother confesses to 
having thoughtlessly cooked and eaten Emma's prized chicken.

Then her brother, in an attempt to make it absolutely clear just how aberrant and unsafe this family is, urinates on her charts. The relationship between Emma and Wesley is a terrible one. She declares "I'm leaving this house". Emma herself is more vocal in her desire to seek escape:

Emma: What type of family is this?

Ella: I tried to stop him but he wouldn't listen.

Emma: (To Wesley) Do you know how long I worked on those charts? I had to do research. I went to the library. I took out books. I spent hours.

Wesley: It's a stupid thing to spend your time on.

Emma: I'm leaving this house! (12)

In the above scene, there is another good example of staging the male violence against women. Wesley is unable to see or understand Emma's attempts. He is too entrapped/imprisoned in his male identity crisis (the male curse) to understand hers. Wesley causes the destruction of his sister dream of self realization. He eliminates any possibility of progression in Emma's life. Subsequently chastised by his mother for only "making things worse," Wesley counters by stating that his cruelty is, in fact, a kindness:

Wesley: I'm opening up new possibilities for her. Now she'll 
have to do something else. It could change her whole direction in life. She'll look back and remember the day her brother pissed all over her charts [just as he himself will recall the night his mother called in the police] and see that day as a turning point in her life.(12)

The essential message of this scene is that "each member of the family is entrapped and cannot communicate with the other members. Taav says that "the family is but an ephemeral construct destined to collapse" (36). Emma's somewhat impractical plan to leave on horseback is thwarted, however, when she is thrown from her horse in the corral. In typical adolescent fashion, Emma's vivid imagination creates a fantasy escape to Mexico. She has dreams to fulfill; she wants to be independent:

Emma: I was going to work on fishing boats. Deep sea fishing. Helping businessmen haul in huge swordfish and barracuda. I was going to work my way along the coast, stopping at all the little towns, speaking Spanish. I was going to learn to be a mechanic and work on four-wheeldrive vehicles that broke down. Transmissions. I could've learned to fix anything. Then I'd learn how to be a short-order cook and write novels on the side. In the kitchen. Kitchen novels. Then I'd get published and disappear into the heart of Mexico. Just like that guy. 
Ella: What guy?

Emma: That guy who wrote Treasure of Sierra Madre.

Ella: When did you see that?

Emma: He had initials for a name. And he disappeared. Nobody knew where to send his royalties. He escaped. (18)

Emma's state shows the freedom of woman in the postmodern period. She dreams of new possibilities and a better life. Unlike the traditional woman who depends on man for living, Emma wants to work and to live her life the way she likes "I like cars. I like travel" (18). She is an ambitious, strong, young lady. Emma is the representative of the new woman of the postmodern period; the woman who is more powerful than man. Certainly Emma is not to be ignored as a powerful voice in this play, but ultimately she is of little consequence to the struggle for identity which becomes central in the play. We hear more about Emma than we see, her scenes being fewer than her brother Wesley.

Frustrated by her inability to stop the impending sale of the farm, she rides her horse through Ellis's bar and riddles the establishment with rifle fire. Although jailed for her destruction of the bar, Emma escapes by making sexual advances to the police sergeant. She returns home to get money and a car in order to launch her life of crime. "It's the perfect self-employment .Crime. No credentials. No diplomas. No overhead. No upkeep. Just straight 
profit. Right off the top "(62). And she is, we are led to believe although this is never confirmed, killed-off-stage-by a car bomb intended for her father, cut down by, in her attempt to escape, the patriarchal inheritance laid out for her. Her ultimate escape, however, is doomed to failure. Emma fails to escape her destiny.

According to Yolks, Shepard's female characters demonstrate their desire to escape "tradition" when they struggle to behave in ways which "explode the traditional view that women are submissive, but they demonstrate the impossibility of escape when they fail to become truly autonomous characters, or when their acquired assertiveness fails to enable them to authentically destroy stereotypical representations of women"(52). This is very clear in the character of Emma. First, she is only able to dream about behaving in ways which do not include stereotypically feminine behaviour and her actual behaviour involves submitting herself to male dominance. When she eventually transforms and begins to behave like a male cowboy, she is presented as being unable to survive.

Shepard clearly privileges his male characters. Rather than portraying the mothers and wives as struggling heroically, Shepard portrays them as "betrayers of their men"( Yolks 50), implying by the way he positions them that while a man's first priority is to himself, a woman's is to her family and to her man. When the men leave, they are portrayed as being simply confused or as seeking something that they need and rightfully deserve (freedom, Independence), but women who leave or who desire to leave are usually portrayed as selfish betrayers of the family and, particularly, of their husbands. 
For Yolks, "Shepard suppresses the possibility that his female characters might positively demonstrate the benefits of behaving in ways which do not include stereotypical behaviour." (50)

The second act of the play starts with Wesley and Emma criticizing their parents. The disunity of the parents leads the children to "function as parents and the parents as children" (Roussel 7). To Emma, her mother is after Taylor because: "She doesn't want to be stuck out here in the boonies for all her life". She knows that her mother is selling the house for her own benefit. Wesley finds that both of his parents are idiots: "She can't think. He can't either" (29). The children are mocking their parents because of their wrong behavior. Both parents are thinking of selling the house instead of thinking of how to protect their family.

Shepard wants to show that the postmodern man's crisis is the result of the postmodern destroyed family. The father-son conflict starts as Weston tells his son that he is going to sell the land and the house. He cannot make the land produce for him, either agriculturally or financially. In a drunken stupor, Weston agrees to sell his family's home to Ellis in order to get enough cash to cover his loan. He searches for his male identity outside home (the domestic curse).

Weston: What do you think of it?

Wesley: I wouldn't sell it.

Weston: ...What good is it? What good's it doing? 
Wesley: It's just here. And we're on it. And we wouldn't be if it got sold. (34)

Wesley refuses the idea of selling the house because it means a lot to him. His house and his identity are linked together, so losing his house means losing his identity. "Wesley represents the new generation that needs to identify its identity through the connection with the land and the roots. Wesley still hopes of finding his identity" (Mokbel 22). Lynda Hart describes Wesley as the hero of the play, the one "who strives to untangle the constrictive cords that at once binds the family together and threatens to cut off the lifeblood of the individual" (69). On the other hand, Weston is totally different from his son. Weston represents an elder generation that has lost hope in the present life. Weston can get rid of his house, the place where he belongs, without being affected because he has already lost his identity. Wesley tries to convince his Dad not to sell the land:

Wesley: We don't have to sell, you know. We could fix the place up.

Weston: It's too late for that. I owe money.

Wesley: I could get a job.

Weston: You're gonna' have to.

Wesley: I will. We could work this place by ourselves. (38)

Land is not the only "commodity" Weston has bought. With his sights set on the future rather than the present, "Weston has bought 
into the ethos and economics of American consumerism" (Peterson 54). The crisis of Weston is not only in thinking about the future but with his irresponsible, foolish and selfish way of acting .His realization of the root of his present dilemma dawns on him in Act III:

Weston: (after pause) I remember now. I was in hock. I was in hock up to my elbows. See, I always figured on the future. I banked on it. I was banking on it getting better. It couldn't get worse, so I figured it'd just get better. I figured that's why everyone wants you to buy things. Buy refrigerators. Buy cars, houses, lots, invest. They wouldn't be so generous if they didn't figure you had it comin' in. At some point it had to be comin' in. So I went along with it. Why not borrow if you know it's coming in. Why not make a touch here and there. They all want you to borrow anyhow. Banks, car lots, investors. The whole thing's geared to invisible money. You never hear the sound of change any more. It's all plastic shuffling back and forth. It's all in everybody's heads. So if that's the case, why not take advantage of it? Why not go in debt for a few grand if all it is numbers? If it's all an idea and nothing's really there, why not take advantage? So I just went along with it, that's all. I just played ball. (59-60)

According to Peterson, "the issue of possession clearly places Curse in the economic order of the socio-political hierarchy" (55). When Weston announces that he has sold the avocado farm 
to the bar owner, Ellis, and plans to buy land in Mexico, one is not sure if this is another "deal" he has devised, or if he is actually aware that his creditors are eager to receive payment and Mexico is merely a convenient escape. The irony of Weston's decision runs deep - he borrows money to obtain worthless land, an action that ultimately costs him ownership of the family ranch, which is far more valuable and potentially far more productive. For Wesley, however, the farm represents roots and stability. He is attuned to the land and its way of life.

Wesley: I was lying there on my back. I could smell the avocado blossoms. I could hear the coyotes. I could hear stock cars squealing [sic] down the street. I could feel myself in my bed in my room in this house in this town in this state in this country. I could feel this county close like it was part of my bones. (7)

Wesley expresses "an almost cosmological view of place and belonging. The sense of security is short-lived, however" (Peterson 55). "I could feel the pace around me like a big, black world. I listened like an animal. My listening was afraid. Afraid of sound. Tense. Like any second something could invade me. Some foreigner. Something undescribable."(7) Wesley is acutely aware of one such invasion: the erosion of the rural tradition in the name of progress. He graphically delineates his vision of the future for Emma after they learn of the impending sale of the farm. 
Wesley: You don't understand what's happening yet, do you?

Emma: With what?

Wesley: The house. You think it's Mr. and Mrs. America who're gonna' buy this place, but it's not. It 's Taylor.

Emma : He's a lawyer .

Wesley : He works for an agency. Land development.

Emma: So what?

Wesley: So it means more than losing a house. It means losing a country.

Emma : You make it sound like an invasion.

Wesley: It is. It's a zombie invasion. Taylor is the head zombie. He's the scout for the other zombies. He's only a sign that more zombies are on their way. They'll be filing through the door pretty soon. (31)

Obviously Wesley does not share the overwhelming desire for escape motivating the other members of his family and is the character most threatened by the prospect of having the property sold. He reveals his motives through his personal investment in the farm.

Ella: Who takes care of the place?

Wesley: Me!

Ella: Ha! Are you kidding? What do you do? Feed a few sheep. Disc the orchard once in a while. Irrigate. What else? 
Wesley: I take care of it.(15 )

Wesley's conviction to keep the land involves more than personal investment. His attitude is also very realistic. Wesley lives there; it is his home:

Weston: What good's it doing?

Wesley: It's just here. And we're on it. And we wouldn't be if it got sold. (34)

His desire to fix up the farm and join the California Avocado Association is a more practical plan than the short-sighted, impractical escapes offered by the other characters.

Each of the other characters maps out an escape route from their lives of intense frustration and spiritual deprivation. Ella opts for the "quick fix": a timely affair with Taylor and enough money for a trip to Europe. Emma's strategy arises from her active, romantically-inclined imagination. For Peterson, "Weston relies on his unswerving belief in the futuristic ideals of commercialism. Ironically and pitifully, it is Wesley who is irrevocably trapped by the end of the drama.’(57)

Actually, Weston's inability to utilize the land to produce for him, financially or agriculturally, also reveals his failure as a businessman and as a family man. From a business standpoint Madachy sees that Weston is completely inept. He borrows money from a less- than-reputable source to acquire a useless, arid plot of 
desert land from a con artist (81). His recounting of the purchase exposes Weston's business incompetence: "Some guy came to the door selling land. So I bought some. [...] [He] looked respectable. Talked a real good line. Said it was an investment for the future. All kinds of great things were going to be developed. Golf courses, shopping centers, banks, sauna baths. All that kinda' stuff. So I bought it" (27). Weston's financial negotiations also reveal his failure as a family man. His willingness to sell the farm, leaving his family with no place to live, no shelter whatsoever, illustrates his inability to maintain a family. His selfish and uncaring behavior, evident throughout the play, is angrily revealed during a drunken rant.

It's like living in a den of vipers! Spies! Conspiracies behind my back! I'M BEING TAKEN FOR A RIDE BY EVERY ONE OF YOU! I'm the one who works! I'm the one who brings home food! THIS IS MY HOUSE! AND I'M SELLING THIS HOUSE! AND I'M TAKING ALL THE MONEY BECAUSE IT'S OWED ME! YOU ALL OWE IT TO ME! EVERY LAST ONE OF YOU! (37)

In the above scene, Weston also tries to show that he is powerful, and that he is superior to other members of his family because he is the father. Hegemonic masculinity is found in societies where man is more powerful and superior to woman. Sawyer states, "hegemonic masculinity is one of the characteristics of the traditional cowboy; however, the postmodern cowboy fails to be powerful" (26). Weston speaks as if he is the 'breadwinner' of the family. In fact, he is jobless and cannot support his family with anything, not even food. 
Weston, then, is trying to prove what he is not.

When Wesley tells him that his mother sold the house for Taylor, he becomes angry. He feels that she is trying to be superior over him. His masculinity is affected, so he turns to be violent. His violence is a way to prove that he is still powerful, especially when he knows that she went out with Taylor: "I'll track her down and shoot them both in their bed. In their hotel bed...I was in war. I know how to kill" (38). Weston speaks as if he is a powerful man although his personality is the opposite of what he tries to show. He wants to use violence against his wife only to prove his manhood. Weston is the symbol of the postmodern American man who is searching for his male identity.

In act III, While Weston walks around the ranch; he realizes that everything he has been searching for is right there on the farm where he and his family live. In a long, mostly-monologue scene, Weston reveals much about how his pursuit of a sense of self-identity is strongly connected to the land:

I started wondering who this was walking around in the orchard at six-thirty in the morning. It didn't feel like me. It was some character in a dark overcoat. [...] It didn't feel like the owner of a piece a' property as nice as this. Then I started to wonder who the owner was. I mean if I didn't feel like the owner, then who was the owner? [...] Then it struck me that I actually was the owner. (51) 
The connection between the land and the man is explicit here. Weston spends much of the play dislocated from everything and everyone around him. He alienates himself from his family and the rest of society, and loses all sense of who he is. But as he examines his land, he is reborn; he already lost everything. Weston, who earlier has been unkempt, drunk, and violent, appears clean shaven, sober, and otherwise chastened. In the above lengthy monologue spoken to Wesley, he recounts taking a peaceful walk at dawn around the avocado orchard during which, according to Roudané, "he experienced a kind of epiphany" (116), suddenly being struck that he actually was the owner, that: "it was me and I was actually the one walking on my own piece of land. And that gave me a great feeling" (51). He then discarded his old dirty clothes and "Just walked through the whole damn house in [his] birthday suit... It was like peeling off a whole person"(51). He followed this with a hot bath, and then a cold bath, and then a hearty farm breakfast cooked from the unexpected profusion of groceries in the refrigerator that came as a surprise, "Just like somebody knew I was going to be reborn this morning or something... Like I was coming back to my life after a long time a' being away" (51-52). He then, as was mentioned earlier, washes everyone's clothes, which engenders a feeling of closeness and interconnectedness.

Several pages later, however, we discover why this apparently cleansing and redemptive ritual does not have the desired effect of restoring a renewed patriarch to his family or bringing a "paradise" regained "for a young person" like Wesley to the farm. For Weston 
believes that simply by declaring himself "Reborn! I'm a whole new person now!" he has achieved his salvation; he no longer needs to "feel guilty... because I don't have to pay for my past now!" (58). Yet, according to Roudané, Shepard apparently rejects "Weston's brand of painless atonement theology as a too easy escape from the ramifications of one's actions: Weston must still pay for his past frailties and sins," (117) not only by the loss of the land but also by the death of his daughter who perishes as his substitute in the car bombing intended for him. So he deserts his family even without saying a goodbye, leaving them to fend off the creditors and criminals that Weston himself set on them through his incompetent business dealings.

Like Weston, Wesley also is searching for his lost male identity. Wesley's ties and curses bind him to his patriarchal duties inherited from his father. This notion of inheritance from the father is brought up several times in the play. For instance, Ella questions why Wesley is not like her father, his grandfather:

Ella: Why aren't you sensitive like your Grandfather was? I always thought you were just like him, but you're not, are you?(13)

Wesley is not like his maternal grandfather because his inheritance does not come from the mother's side of the family but from the father's. Emma explains this connection between father and son when describing her father's personality to her mother's "lawyer" Taylor. Emma says: 
A short fuse they call it. Runs in the family. His father was just like him. And his father before him. Wesley is just like Pop, too. Like liquid dynamite.... It's chemical. It's the same thing that makes him drink. Something in the blood. Hereditary. Highly dangerous. (21)

Although Emma is no doubt trying to scare off this "lawyer friend" of her mother, her statement about the legacy from father to son proves to be quite accurate in the course of the play. Weston encourages this interpretation in a later conversation with Wesley wherein Weston refers to the "poison" he has inside him:

Weston: Yes, you do. I can see that you do. My poison scares you.

Wesley: Doesn't scare me.

Weston: No?

Wesley: No.

Weston: Good. You're growing up. I never saw my old man's poison until I was much older than you. Much older. And then you know how I recognized it?

Wesley: How?

Weston: Because I saw myself infected with it. That's how. I saw me carrying it around. His poison in my body. You think that's fair?

Wesley: I don't know. 
Weston: Well, what do you think? You think I asked for it? $(35-36)$

This "poison" is, then, explained as the unavoidable result of being a son and is evidently the male "curse" just as menstruation is set up within the play as the female "curse." By the last act, Weston manages to cleanse himself at least temporarily of some of this poison through stripping himself of his old clothes, Wesley soon tries this method only to reappear in Weston's old discarded clothes. $\mathrm{He}$ describes the experience to Emma:

I started putting all his clothes on. His baseball cap, his tennis shoes, his overcoat. And every time I put one thing on it seemed like a part of him was growing on me. I could feel him taking over me...I could feel myself retreating. I could feel him coming in and me going out. Just like the change of the guards. (61)

Emma's matter of-fact response undercuts Wesley's sense of selfconflict. She tells him simply: "Well don't eat your heart out about it. You did the best you could" (61). But Wesley continues to see himself as compelled to reenact his father for reasons he cannot fathom. As he says, "I didn't do a thing...I just grew up here" (62). In Wesley's case, the strongest image is of his father, whom Wesley becomes by the end of the play. Ultimately, he is just as doomed as Emma. 
In this scene, Morimoto states that "we must pay attention to the fact that Wesley himself feels that he seems to inherit something from his father by wearing his father's costumes". Furthermore, he sees that Wesley wears his father's clothes "willingly". We can regard this fact as "the evidence of his will that he tries to replace his father's position somehow" (123). The son feels that he is destined to follow the same track.

After Wesley wears his father's costumes, he begins to show similar acts of violence as his father. He becomes clearly conscious of the inheritance and tries to do the same way that his father does at the beginning of the third act, such as taking all his clothes off and taking a bath several times. Morimoto states: "after all, the son also follows the completely same course as his father and results in the downfall. Furthermore, in fact, the father himself cannot escape from the same poison" (124). He said: "I tried his remedy and it didn't work."'(61)

However, Morimoto says that "we see a complete reversal of the roles between them in the third act" (127). At the beginning of Curse, the father, Weston, destroys the door of the house on a drunken impulse. On the other hand, the son, Wesley, cleans up the chips of the broken door in silence, that is, he settles the problem his father produced instead of his father himself. In act III, Wesley suddenly shows his violent aspect. Wesley's love for the lamb that he took care of before has cooled off and he finally kills it. The lamb is a symbol of Wesley himself. His killing of the lamb shows that he is sure there is no way out for him. He is finished. On the other hand, Weston begins 
to show the strong affection for the lamb. According to Morimoto, in examining Shepard's family trilogy, we should notice that almost "all the male characters show their violent nature here and there". From the viewpoint of the blood theme; he considers these acts of violence as "the most remarkable representation of the heritage by blood relationship from one generation to another.'(124)

Then, at the end of the play, Weston, that his debts are past due, has a1ready escaped. Weston launches into an explanation as to how and why he failed as a father:

I couldn't stand it here. I couldn't stand the idea that everything would be the same. That every morning it would be the same. I kept looking for it out there somewhere. I kept trying to piece it together. The jumps. I couldn't figure out the jumps. From being born, to growing up, to droppin' bombs, to having kids, to hittin' bars, to this. It all turned around on me somehow.... I kept looking for it somewhere. And all the time it was right inside this house.(60)

Taav clarifies that Weston, in this confession fraught with contradictions, sees himself alternately as a "victim, a man abruptly and inexplicably dropped down into situations over which he had no control", and conversely as someone presented with "clear opportunities for happiness" (right inside this house) (43) but who failed consistently to recognize them. 
Weston: Where should I go?

Wesley: How 'bout Mexico?

Weston: Mexico? Yea, that where everybody escapes to, right? it's full of escape artists down here. I could go down there and get lost. I could disappear. I could start a whole new life down there.

Wesley: Maybe (60)

Wesley recognizes that, despite his father's intentions to start over in Mexico, searching for his male identity, such an attempt is not possible. Weston may escape from his creditors, but Wesley knows that his father is entrapped by more pervasive influences: habit and heredity.

With Emma dead and Weston having fled to Mexico, the play ends as it had begun: with Ella and Wesley alone together on stage. Now, however, there is no family to save, no fate left to contend, nothing left to argue about. Instead, mother and son complete a story about a huge eagle begun by Weston at the very beginning of Act Three:

Weston: One time I was out in the fields doing the castrating.... Well, maybe I had a dozen spring ram lambs to do out there....Well, I was working away out there when I feel this shadow cross over me ... this giant eagle.... He was after these testes.... So I decided to oblige him ... and 
threw a few on the shed roof ... all of a sudden he comes. Just like a thunder clap. Blam!. . . . I had tostand up on that one. Somethin' brought me straight off the ground and I started yellin' my head off.... Cheerin for that eagle. (49)

What Weston neglects to mention, however, and what Ella and Wesley focus upon, is the arrival of a cat.

Ella: You remember. What happens next?

Wesley: A cat comes.

Ella: That's right. A big tom cat comes. Right out in the fields ..And he jumps up on top of that roof to sniff around in all the entrails or whatever it was.

Wesley: (still with back to her) And that eagle comes down and picks up the cat in his talons and carries him screaming off into the sky.

Ella: (staring at lamb) That's right. And they fight. They fight like crazy in the middle of the sky. The cat's tearing his chest out, and the eagle's trying to drop him, but the cat won't let go because he knows if he falls he'll die.

Wesley: And the eagle's being torn apart in midair. The eagle's trying to free himself from the cat, and the cat won 't let go. 
Ella: And they come crashing down to the earth. Both of them come crashing down. Like one whole thing. (65-66)

For Taav, "Whether it was some hereditary predilection or free will that brought Weston "the eagle" to Ella "the cat," it was nonetheless this conflict, this "cursed" partnership between two beasts ill-suited to the other's purposes and needs"(45). This not only led to the destruction of both but also to the father's curse being passed down to the son and daughter they had engendered.

The closing story told by both Ella and Wesley resonates with significance concerning this central conflict of the play, and it can also be a very considerable image that helps in staging the male identity crisis. This story may be regarded as the continuation of the story Weston begins when he confessed to the lamb at the beginning of the third act of an eagle and a tomcat locked in mortal combat, an image which critics have read variously to describe the fate of the family or of men and women who cannot survive either together or apart. The warring parties of this showdown, the cat and the eagle, began their fight over the testes of lambs, over what Weston refers to as "little remnants of manlihood" (50) Ella and Wesley transform the story a little and Ella says the cause of the battle between the eagle and the cat is "the entrails" of the lambs. But, according to Weston's story, it seems to be the testes of the castrated lambs. We can recognize Weston's version of the story to be the plausible one because of the fact that Weston often told the story to his family. For Michitaka Morimoto "The testes of the lambs can be regarded as the most remarkable thing to show the essence of the masculinity."(132) 
The mortal combat occurs in this play, once more, over issues of manhood-over male identity. In this battle there is no possibility of a winner because together "they come crashing down to the earth". Both of them come crashing down. According to Peterson "the final image of the cat and eagle falling to the ground in mutual destruction does not provide an escape from the primary dialectics of men and women." (79)

However, we can see the meaning of the battle between the eagle and the cat differently. That is, the image of the battle between the eagle and the cat seems to symbolize the "conflict between father and son", that is, in this case, Weston and Wesley. Morimoto supports this reading when states that:

The target of this conflict seems to be the masculinity to get the position as the head of the family. This seems to be symbolized by the testes of the lambs. The fact that both the eagle and the cat are pointed out by the pronoun "he" supports this idea. And the result that the eagle and the cat fall down together means the downfall of father and son together. And, it also means the downfall of their family as a whole. This shows the menace to the power of heredity. (132)

Still a third meaning can be gleaned from this story: the cat can be a symbol for both Ella and Wesley. This symbolic story of the eagle and the cat is very significant of the male identity crisis. It clarifies the continuous male struggle for his identity whether with women or with 
other men. The story shows also that this conflict is destructive for both sides and no one will be a winner.

In Curse, the father and the son face the male identity crisis due to the lack of family unity, and from the first moment of the play they search for their lost male identity. Their crises are staged through their relation with each other and with the other members of the family: the mother and the daughter. "Wesley represents the postmodern cowboy who fails to find a place for himself in his family" (Mokbel 23). His father, mother, and sister affect him negatively and his relation with each of them reveals the impossibility of communication and unity among family members. Not only has the destruction of his family affected him, but also the loss of his home and land. On the other hand, the father belongs to an elder generation. "The father's crisis shows that in the postmodern era, man is frail and hopeless. As a result, Shepard's postmodern hero lacks all the characteristics of the traditional American cowboy" (Ibid 23). Shepard's new image of the cowboy shows how the American man's character has shifted from a heroic figure to a destroyed one. 


\section{Bibliography}

- Adler, Thomas, "Repetition and Regression in Curse of the Starving Class and Buried Child", The Cambridge Companion to Sam Shepard. Ed. Roudane, Mathew. Cambridge University Press, Cambridge, 2002.

- Barnhisel, Greg. "Critical Essay on Curse of the Starving Class." Drama for Students. Ed. Jennifer Smith. Vol. 14. Detroit Gale, 2002. Literature ResourceCenter.Web.15Aug.2012.<http://go.galegroup.com/ps /i.do?id=GALE $\%$ 7CH1420040617\&v=2.1\&u=aub\&it=r\&p=Li $\mathrm{tRC} \& \mathrm{sw}=\mathrm{w}>$

- Bonnie Marranca, ed., "Alphabetical Shepard: The Play of Words," in American Dreams: The Imagination of Sam Shepard (New York: Performing Arts Journal Publications, 1981), p.28. . Academic Search Premier. EBSCO. American University in Cairo, Egy. 27 April 2013.<www.epnet.com>

- Boss, P. and Greenberg. Family Boundary Ambiguity: A New Variable in Family Stress Theory. Family Process, 23:535-46, 1984

- Burke, Kenneth. The Philosophy of Literary Form: Studies in Symbolic Action. 3d. ed. Berkeley: University of California Press, 1973. 
- Coen, Stephanie. "Things at Stake Here" American Theatre 13.7 (Sept. 1996): 28 http://hdl.handle.net/11094/25179.

Academic Search Premier. EBSCO. American University in Cairo, Egy. 27 April 2013.<www.epnet.com>

- Culler, Jonathan. On Deconstruction. Ithica, New York: Cornell University Press, 1984.

- De Rose, David. Sam Shepard. Twayne Publishers. New York. 1992

- Galens, David. Drama for Students. Volume 3, Detroit: Gale, New York, 1998.

- Hall, Ann C. A Kind of Alaska: Women in the Plays of O'Neill, Pinter, and Shepard, Southern Illinois University Press, Carbondale, (1993).

- Hart, Lynda, “Sam Shepard's Pornographic Visions: Depictions of Women in his Plays," Studies in the Literary Imagination 2: 69-82. (1988)

- Hart, Lynda. Sam Shepard's Metaphorical Stages. New York: Greenwood, 1987.

- Hearn, Jeff. Men in the Public Eye: The Construction and Deconstruction of Public Men and Public Patriarchies. London: Routledge,1992. 
- King, Kimball. Sam Shepard : A Casebook. New York : Garland, 1988.

- Krasner, D. American Drama 1945-2000: An Introduction. MA, USA: Blackwell Publishing, 2006.

- Madachy, Paul Seamus. "The Nightmare of the Nation: Sam Shepard and the Paradox of American Identity." Diss. 


\section{University of Maryland, 2003.}

- Marranca, Bonnie. "Alphabetical Shepard: The Play of Words." American Dreams: The Imagination of Sam Shepard, New York: PAJ Publication, 1981. 13-33.

- Michitaka Morimoto. "Male Conflicts in Sam Shepard's Family Trilogy.” Osaka Literary Review. 42 P.121-P.138. (2003-12-24). http://hdl.handle.net/11094/25179. Academic Search Premier. EBSCO. American University in Cairo, Egy. 27 April 2013.< www.epnet.com>

- Mokbel, Sahar Ahmad. "The Postmodern American Man in Sam Shepard's Curse of The Starving Class". WEI International Academic Conference Proceedings. (Antalya, Turkey) January 1416, 2013. Academic Search Premier. EBSCO. American University in Cairo, Egy. 27 April 2013.<www.epnet.com>

- Nightingale, Benedict. "Even Minimal Shepard is Food for Thought," New York Times, 25 September, 1983, sec. 2, 5. Academic Search Premier. EBSCO. American University in Cairo, Egy. 27 April 2013.<www.epnet.com>

- Peterson, Jane Temple. "Sam Shepard's family trilogy: Analysis and assessment.” Diss. University of Missouri- Columbia, 1989.

- Rosen, Carol. "Dynamite in the Blood", Sam Shepard: A 'Poetic Rodeo', Palgrave Macmillan, New York, 2004.

- Roudané, Matthew. The Cambridge Companion to Sam Shepard. Cambridge University Press: Cambridge, England, 2002. 
- Savran, David. "Sam Shepard's Conceptual Prison: Action and the Unseen Hand," Theatre Journal, 36 (March 1984), Academic Search Premier. EBSCO. American University in Cairo, Egy. 27 April 2013.<www.epnet.com>

- Shapiro, Stephen A. Manhood: A New Definition. New York: G. P. Putnam's Sons, 1984.

- Shepard, Sam. Curse of the Starving Class: a Play in Three Acts. New York (440 Park Ave. South, New York 10016): Dramatists Play Service, [1991], c1976.

- Smith, Jennifer, "Overview: Curse of the Starving Class." Drama for Students. Vol. 14. Detroit: Gale, 2002.Literature Resource Center. Web. 15

Aug.2012.<http://go.galegroup.com/ps/i.do?id=GALE\%7CH143000 $5745 \& v=2.1 \& u=a u b \& i t=r \& p=L i t R C \& s w=w>$

- Taav, Michael. A Body across the Map: The Father-Son Plays of Sam Shepard. Peter Lang, New York, 2000.

- Tucher, Martin. Sam Shepard. New York : Continuum, 1992.

- Whiting, Charles G. "Images of Women in Shepard's Theatre." Modern Drama 33 (1990): 494-506.

- Yolks, Carolyn Dana. "The Representation of Women in the Plays of Sam Shepard”. Diss. Rhodes University, 1994. 